\title{
Development Features of Heat Power Industry Legislation in Russia
}

\author{
Ekaterina MEDNIKOVA ${ }^{1}$, Valery STENNIKOV ${ }^{2}$, Ivan POSTNIKOV ${ }^{3}$, \\ Andrey PENKOVSKII ${ }^{4 *}$ \\ ${ }^{1-4}$ Melentiev Energy Systems Institute of Siberian Branch of the Russian Academy of Sciences, \\ Lermontov St. 130, Irkutsk, 664033, Russia
}

\begin{abstract}
In Russia, the legislative support for the construction and operation of heating systems is permanently developing and improving. The Federal law "On heat supply" adopted in $\mathbf{2 0 1 0}$ is the basic and most important document that regulates the work of heating systems. Moreover, the country has more than 10 additional documents that regulate this industry, and a great number of documents that establish rules for building and operating energy systems. The paper presents the main documents that regulate the heat supply industry in the Russian Federation, and a brief description of the main stages of heating system life cycle and problems solved in each of them. Despite the national policy of energy conservation and energy efficiency enhancement, there are still problems related to heat supply management due to large extension, complexity and a variety of types and structures of the systems. The main cause of the poor heat supply efficiency in Russia is explained by a considerable change in the structure of heat loads that has occurred of late years, a decrease in the loading of the main generating equipment and heat networks, which amid other things is fostered by an increasing wear of the systems. Upgrading of generating capacities and heat networks is considered in the framework of long-term investment projects for their modernization and expansion. The obtained solutions are reflected in the Schemes of urban heat supply. This paper proposes solutions aimed at enhancing the effectiveness of decisions made in the field of heat supply. It formulates the proposals on organization and regulation of the activities of all the participants in heat supply in the stage of long-term planning of heating system expansion, because well-founded and rational planning of construction and expansion of the systems is a basis for their efficient operation.
\end{abstract}

Keywords - Cooperation; district heating systems; energy market; energy planning; heat supply; utility regulation

\section{INTRODUCTION}

Russia has a unique experience in establishment and management of district heating systems (DHS). Large-scale construction of centralized heat sources began as part of the GOERLO plan in the 1970s [1], [2]. The heating systems of the country differ in complexity and have to operate in severe climatic conditions of the Extreme North and in the Southwestern regions with warm and mild climate. Heat sources in Russia operate on different fuels depending on fuel supply in a region.

Despite the long-term experience in operation of DHS in Russia, the development of legal and regulatory framework in this field started only several years ago. The federal law "On heat supply" [3] was adopted in 2010 and it is the foundation and the most important

\footnotetext{
* Corresponding author.

E-mail address: penkoffsky@ isem.irk.ru
} 
document that regulates the work of DHS. Technical solutions related to district heating however start in the stage of the development of urban planning documentation of that is regulated by a number of documents [4]-[6].

According to these documents, a General city plan and a Draft area plan should be developed and approved. Moreover, these documents identify the areas of district and individual heating; highlight the sites for location of heat sources and their sanitary protection zones; the sites for laying heat pipelines; allocate the areas for prospective construction of sources, and address the issue of heat supply to the prospective urban housing.

In European countries, the development of a legal framework related to heat supply started with the development of district heating. In the Scandinavian countries, the active development of the district heating began after the oil crisis of 1984 [2], [7], [8]. It was the main idea of energy law to avoid significant increasing energy prices. This made it possible to reduce oil consumption and improve the environmental situation. Since then, the reduction of harmful emissions into the atmosphere and consumption of fossil fuels has become a priority in the energy policy of these countries.

Scandinavian countries are developing municipal energy plans that include territory-zoning maps by type of heat supply or levels of heat density [9]-[13]. According to the level of heat density, three types of heat supply are considered: district and individual heating, centralized gas supply. Introduction of innovative energy-efficient technologies in the construction and zero-energy buildings will reduce the heat consumption. This will inevitably lead to changes in the heat density maps and energy plans of cities [14]. The main document which describes development of DHS is The Heat roadmap Europe [15]-[18]. It states that district heating will be suitable in dense urban areas, while local heat pumps and biomass boilers will be suitable in other areas.

In Denmark, Regulation of the heat energy market is carried out in accordance with The First Heat Supply Law of 1979. Specific heat price in the country is regulated by the Government and formed based on the principle of zero profitability. Cooperation of science, energy companies and government allows to improve energy-efficiency of heat supply in areas with low heat demand and expand the district heating area [19], [20]. In Denmark, energy planning is well developed, it promotes extension and construction of energy efficient DHS [21]-[23].

In Sweden, the operation of the DHS is regulated by District Heating Act, which also contains information about the district heating enterprise's prices for heat supply and for a connection to the district heating operation.

In Finland, consumers have the right to choose a way of heat supply and there are no Government subsidies [24]-[25].

In China, heat is generated at large combined heat and power plants (CHPP), Government regulates heat tariffs, the consumer can choose between district and individual heating. At the same time, in China since 2007, DHS and construction of CHPP have been the priorities within energy efficiency policy [26], [27].

Russian energy policy in heat supply market has its own special features. The activity of district heating enterprises and development of design and technical documentation in the field of heat supply are regulated by a set of legal bills that determine the order and time of connecting new consumers, rules of tariff setting, conditions for heat supply to consumers, and other issues [28]-[34]. 


\section{MAIN PART}

\subsection{Current Heat Polices in Russia}

The Federal law "On heat supply" [3] regulates heat production, transmission, and consumption in district heating systems; establishment, operation and expansion of heating systems; competences of the public authorities, local authorities of settlements and municipal districts on regulation and management in the field of heat supply; rights and duties of heat consumers, heat supply and heat network entities. According to the amendments to this law adopted in 2017, there are changes in the system of tariff setting regulation with a switch from state regulation of all tariffs in heat supply to the establishment of a limiting level of heat price for the end consumers, i.e. the level of the so called "alternative boiler plant". The price will be calculated based on the heat cost to be paid by the consumers in the case of the construction of their own boiler plant. There should be price zones within which heat supply will be a responsibility of unified heat supply organizations. The unified heat supply organization shall implement the measures developed in the Scheme of heat supply and aimed at constructing, reconstructing, and modernizing heat supply facilities. The organizations to be established will be responsible for the quality of rendered services and setting the maximum admissible heat supply interruption time. It is worth noting that an excessive increase in tariffs can result in a refusal of the consumer from district heat supply and their switch to individual sources (decentralized heat supply). According to the current legislation, the consumer is not limited in their choice of a heat source. At the same time spontaneous development of the decentralized sector will decrease the efficiency of large-scale DHS and increase specific costs in systems.

The principles of heat tariff setting are regulated by the Resolution of the Government of the Russian Federation of October 22, 2012 No. 1075 "On pricing in heat supply" [34]. The Federal law of December 302012 No. 291 - FL "On the introduction of amendments in individual legislative bills of the Russian Federation on the improvement of tariff regulation in the field of electricity, heat, gas, and water supply, and water removal" establishes the legal framework for the introduction of a long-term tariff regulation, in particular for heat supply.

The investment activity and territorial planning on creation, operation, and expansion of DHS is regulated by the Resolution of the Government No. 410 of 05.05 .2014 "On the order of coordination and approval of investment programs of organizations that perform regulated kinds of activity in the field of heat supply and requirements for composition and scope of such programs" (except for such programs approved according to the legislation of the Russian Federation on power industry) and Resolution of the Government of the Russian Federation of February 22, 2012, No. 154 "On requirements for the schemes of heat supply, order of their development and approval" [29]. It is worthwhile to note however that these documents do not highlight the issue of energy efficient zoning of the territory by heat supply type with identification of areas for district and individual heating. The boundaries of the individual heating areas are determined in the Scheme of urban heat supply, but this concerns only their current state, while the areas of new housing are not mentioned, and consequently no reduction in the heat supply costs for the consumer is planned. The efficiency of connecting new consumers is assessed by the criterion of effective he at supply radius (EHSR). EHSR is the maximum distance along the heat network beyond which the connection of new consumers leads to a rise in the specific costs in the DHS. This criterion is calculated for each heat source and makes it possible to make a decision on the connection of new consumers. There is however still no officially approved technique for the EHSR calculation. 
Technical regulation of the quality of the supplied resource and rules of rendering municipal services is performed by the Resolution of the Government of the Russian Federation of May 6, 2011 No. 354 "On rendering municipal services to the owners and users of premises in blocks of flats and houses". The issues of the energy saving policy are reflected in [31]. In 2010-2011, each region of Russia developed and approved Programs for energy conservation and enhancement of energy efficiency, but their target indicators have not been achieved yet. This is explained first of all by insufficient stimulation of the adoption of energy efficient equipment, improvement in energy efficiency of buildings, the use of renewable energy heat sources, etc. In the last years there have been positive changes in the field of heat supply. According to the main provisions of the current legislation, Russia started to develop Schemes of heat supply to the settlements, plan Programs for modernization of heat facilities in the regions of the country and carry out energy examination of industrial enterprises, and make organizational restructuring.

Russia's energy policy similar to that in the other countries is oriented to an increase in the energy efficiency, the expansion of renewable energy sources, quality upgrading of energy facilities, and reduction in the energy-to-GDP ratio. To this end, the national and regional programs are developed: "Energy strategy of Russia, Energy conservation and improvement in energy efficiency of Russia and its regions, Scheme and program for national and regional development of electric power industry, Scheme of heat supply to the cities and settlements, energy balances of the regions, etc. These programs propose projects for modernization of the industry, and its further development, plan the adoption of innovative technologies and renewable energy sources. The implementation of these solutions in practice however, should be more active.

Despite the extensive legislative framework, there are still management difficulties in the field of heat supply and energy saving because of large scale, complexity, different types and structure of the systems. Such properties of the systems complicate the management and regulation of the activities of all participants in the heat market. At the same time there is still cross-subsidization of the industry. The regulatory acts adopted to change the situation are not supported by the instruments required for their implementation. There have been no changes made in the system of taxation of heat supply entities to increase the stimulating functions of taxes (tax holidays, exemption of taxes on the profit part to be invested). The interaction between the heat supply stakeholders such as State, science, energy companies, design organizations and consumers is not active enough.

In this regard, it is necessary to build a hierarchical system of public administration and regulation in the sphere of heat supply for development and implementation of the appropriate state policy, including the state stimulation of innovative development of this industry, as well as to create a package of information and methodological materials on the development and operation of heating systems and bring it in accordance with the laws and regulations of the state.

\subsection{Heat Planning as a Way to Overcome the Crisis}

An analysis of the main regulatory documents has demonstrated that on the one hand the goal of the state policy in the field of heat supply is reliable and quality heat supply, while on the other hand, this requires an additional study on the mechanisms to achieve the set goal, and a number of crucial documents such as Strategy of Russia's heat power industry development, a methodological framework to plan the industry development and design the heat supply Schemes. 
The current situation in the heat supply calls for alterations not only in the legal documents but also in the management of DHS development and operation, including a change in the structure of the systems, composition of heat sources, technology of operation, a system of tariff setting, organization of heat supply, etc.

Therefore, an essential component of the enhancement of heat supply efficiency and quality is rational planning in all the stages of life cycle of the DHS.

Life cycle of DHS and its elements from an idea of its construction to the expiration of its service life can be represented by the following main stages [35], [36]:

- Long-term forecasting for the period of 25-30 years (development of sections on heat supply in general plans of cities and schemes of district planning, industrial forecasts of heat supply expansion, section in the energy strategy of the country);

- Long-term planning for the period of 15-20 years (development of a long-term target complex program and a technical and economic report on the national heat supply, development of general plans of cities, detailed planning);

- Prospective design for the period of 10-15 years (development of schemes for development of the industry and heat supply patterns for various territorial entities);

- Medium-term planning for the period before 5 years (development of supporting materials, design);

- Construction and erection;

- Operative planning for the next heating season;

- Operation of the system (a standard service life of the main components of DHS is 30-50 year);

- Disassembling of heating system components after their service life expiration.

The extent to which the individual issues of heating system development are studied depends on the time levels of their consideration. Planning of DHS development is focused on the issues interrelated with one another both in one calculation period and in various time periods. This is how the horizontal (object) and vertical (time) structures are viewed. The scope of the problems of heating system development is presented in Table 1.

TABle 1. SCOPE OF THE OPtimization Problems of HeAting SySTEM DEVELOPMENT

\begin{tabular}{|c|c|c|c|}
\hline \multicolumn{4}{|c|}{ Heating system } \\
\hline Time level & $\begin{array}{l}\text { Heat and electricity } \\
\text { consumption }\end{array}$ & Heat sources & Heat networks \\
\hline 30 years & $\begin{array}{l}\text { Projection of national, and } \\
\text { regional heat consumption } \\
\text { Projection of national and } \\
\text { regional electricity } \\
\text { consumption }\end{array}$ & $\begin{array}{l}\text { Projection of the heat output by the } \\
\text { sources with focus on the share of } \\
\text { cogeneration plants } \\
\text { Target indicators of effective heat } \\
\text { source operation } \\
\text { Predictive estimation of the } \\
\text { environmental impact of heat sources }\end{array}$ & $\begin{array}{l}\text { Predictive estimation of the heat } \\
\text { network extension and heat } \\
\text { losses } \\
\text { Aggregate estimation of } \\
\text { required investment in the } \\
\text { construction and modernization } \\
\text { of equipment }\end{array}$ \\
\hline 20 years & $\begin{array}{l}\text { Projection of national, regional } \\
\text { and urban heat consumption } \\
\text { levels with focus on the main } \\
\text { consumer groups. Forecast of } \\
\text { national, regional and urban } \\
\text { electricity consumption }\end{array}$ & $\begin{array}{l}\text { Projection of heat output by type of } \\
\text { sources for regions and cities } \\
\text { Planning of conditions and type of } \\
\text { urban fuel supply } \\
\text { Zoning of the urban territory by type } \\
\text { of heat supply } \\
\text { Planning of sites for allocation of heat } \\
\text { sources in a city in the district heating } \\
\text { zone }\end{array}$ & $\begin{array}{l}\text { Planning of target effectiveness } \\
\text { indices of heat network } \\
\text { operation } \\
\text { Preliminary choice of heat } \\
\text { carrier parameters } \\
\text { Assignment of sites for the } \\
\text { allocation of heat network } \\
\text { infrastructure facilities }\end{array}$ \\
\hline
\end{tabular}




\begin{tabular}{|c|c|c|c|}
\hline \multicolumn{4}{|c|}{ Heating system } \\
\hline Time level & $\begin{array}{l}\text { Heat and electricity } \\
\text { consumption }\end{array}$ & Heat sources & Heat networks \\
\hline & & \multirow{5}{*}{$\begin{array}{l}\text { Assessment of reliability of heat } \\
\text { sources } \\
\text { Determination of optimal level of heat } \\
\text { supply centralization in a city } \\
\text { Calculation of consumption volumes } \\
\text { for each fuel type; Assessment of } \\
\text { electricity generated in a cogeneration } \\
\text { cycle }\end{array}$} & $\begin{array}{l}\text { Determination of time and order } \\
\text { for consumer connection to }\end{array}$ \\
\hline & & & heating systems \\
\hline & & & Determination of conditions for \\
\hline & & & $\begin{array}{l}\text { connection of the consumer to } \\
\text { the heating system }\end{array}$ \\
\hline & & & $\begin{array}{l}\text { Calculation of hydraulic } \\
\text { conditions in the heat network }\end{array}$ \\
\hline & & $\begin{array}{l}\text { Assessment of investment and } \\
\text { feasibility studies of projects }\end{array}$ & $\begin{array}{l}\text { Assessment of reliability of the } \\
\text { heat network operation }\end{array}$ \\
\hline & & \multirow[t]{3}{*}{$\begin{array}{l}\text { Assessment of material and labour } \\
\text { resources }\end{array}$} & $\begin{array}{l}\text { Determination of the heat } \\
\text { pipeline laying types, method of } \\
\text { insulation and choice of the } \\
\text { main construction structures }\end{array}$ \\
\hline & & & $\begin{array}{l}\text { Assessment of investment and } \\
\text { feasibility studies of projects }\end{array}$ \\
\hline & & & $\begin{array}{l}\text { Assessment of material and } \\
\text { labour resources }\end{array}$ \\
\hline
\end{tabular}

The documents concerned with the issues of energy planning and heat supply development in particular are based on the following input information [6], [29], [32], [37]-[41]:

- Normative regulatory acts of the public authorities of relevant entities of the Russian Federation and bodies of local governments on regulation of city construction activities, land management, protection of natural resources, monuments of history and culture and on the issues of heat supply and tariff setting;

- Cartographic information;

- Strategies (programs) for development of individual economic branches, priority national projects, interstate programs, programs for social and economic development of the entities of the Russian Federation, plans and programs for comprehensive social and economic development of municipal entities;

- Statistical and other information.

According to the requirements presented in the regulatory documents [3], [6], [29], [34], [38], [39], the following activities should be performed on a city plan:

- Describe existing and prospective zones of individual heat sources;

- Describe existing and prospective areas of DHS and heat sources;

- Calculate effective heat supply radius to determine the conditions under which the connection of new heat consuming plants or those increasing heat load to the DHS is ineffective due to an increase in the total costs in the considered system per unit of heat capacity, determined for the service area of each heat source;

- Describe the preserved and designed transmission networks of the engineering infrastructure, i.e. water pipeline, sewage, heat supply, gas supply, etc., mark the sites for their allocation;

- Describe the main technical and economic indices of the general plan of the settlement, including the volume of heat consumption, output of district and local heat sources, extension of heat networks.

To fully perform the indicated tasks, the methods intended to plan heat supply development should meet the following requirements: 
- Consider external and internal factors that influence the development of heat supply to the settlements (climatic conditions, fuel supply, specific features of laying the pipelines, consideration of the existing part of DHS, etc.);

- Ensure operability under uncertainty of the initial information;

- Have accuracy of the model, sufficient for the greatest approximation to the properties of a real-world system to be modelled;

- Provide the necessary accuracy of calculation results;

- Be universal (this characterized the completeness of reflecting real object properties in a model);

- Be simple and convenient for use.

For successful accomplishment of the set goals to plan the development and operation of heat supply it is necessary to intensify the cooperation among all the participants involved in heat supply, including not only heat supply entities, consumers and State, but also design and scientific organizations. The solutions to be obtained by the latter will be the basis for the investment programs and programs for the development of the industry. Conceptually, the life cycle stages in a simplified form include the following: forecasting, planning, design, construction and operation.

State adopts the documents that regulate the activities of the stakeholders in certain stages of the life cycle of DHS, establishes the order of relations between all participants in the heat market (in particular establishes the responsibility of heat supply organizations to the consumer in case of breaking their obligations, responsibility of scientific and design organizations for the quality of the developed projects, and responsibility of consumers for untimely payment of the heat supply services). The State also develops and implements the measures to stimulate the use of renewable energy sources, carries out the explanatory work with population, approves the boundaries of land areas for construction of heat sources and network infrastructure facilities. First of all, the authorities approve the vector of further heat supply development. Therefore, it is necessary to develop and annually update the state program for heat supply development in Russia.

The scientific organizations are involved in the development of mathematical models, applied methodology and computational tools for solving the problems presented in Table 1 .

The projection of electricity and heat supply is made based on the following data: the number of population, area of buildings, volume of industrial production, specific indices of energy consumption for various industries, etc. To make the calculations it is necessary to analyse retrospective data on all indices, consider the data, assumed in the forecast of socioeconomic development of the country and regions, and coordinate the forecast with the conditions of fuel supply in the region. To solve the optimization problems, the mathematical models are constructed and the methods of linear and nonlinear programming are employed. Moreover, they develop and/or assess the effectiveness of the adoption of new technologies [42], [43] and smart energy equipment in DHS [44]. The scientific organizations cooperate with the authorities to develop the regulatory documents aimed at assessing the effectiveness and viability of the decisions made by the State.

The design and construction organizations are involved in the engineering studies, development of design estimation documentation for concrete projects in the field of heat power industry, coordination of the project with inspecting bodies and experts, and monitor the project both during the construction of a facility and during its operation.

Heat supply companies are involved in solving the entire cycle of problems because they bear responsibility for providing quality and reliable heat supply to consumers. Each heat 
supply company develops their own investment program that should include the results presented in the Scheme of urban heat supply.

The consumer is the main participant in the heat market, because they set demand for heat. The system of district heating cannot function without consumers. In turn, the consumer has to timely pay for the heat supply services, rationally use energy resources and meter their use, and in the case of transition to the next generation DHS, submit short-term and long-term forecasts of heat needs. It is worth noting that in all the stages of DHS life cycle the interaction of all stakeholders is organized harmonically. We propose basic principles of interaction between heat market participants.

State and heat supply entities interact with all stakeholders. Thereby, the scheme may have no direct relation between the State and participants, this relation though is implemented through the regulatory acts, and meet the requirements. Design organizations develop design documentation for the projects and solutions obtained from optimization calculations. The consumer can also use all their services while organizing their own heat supply.

Primarily, the construction of efficient and reliable heat supply systems is connected with the development of measures of municipally heat supply scheme reconstruction and includes a set of tasks. These tasks can be divided into three stages, as it is shown in Fig. 1.

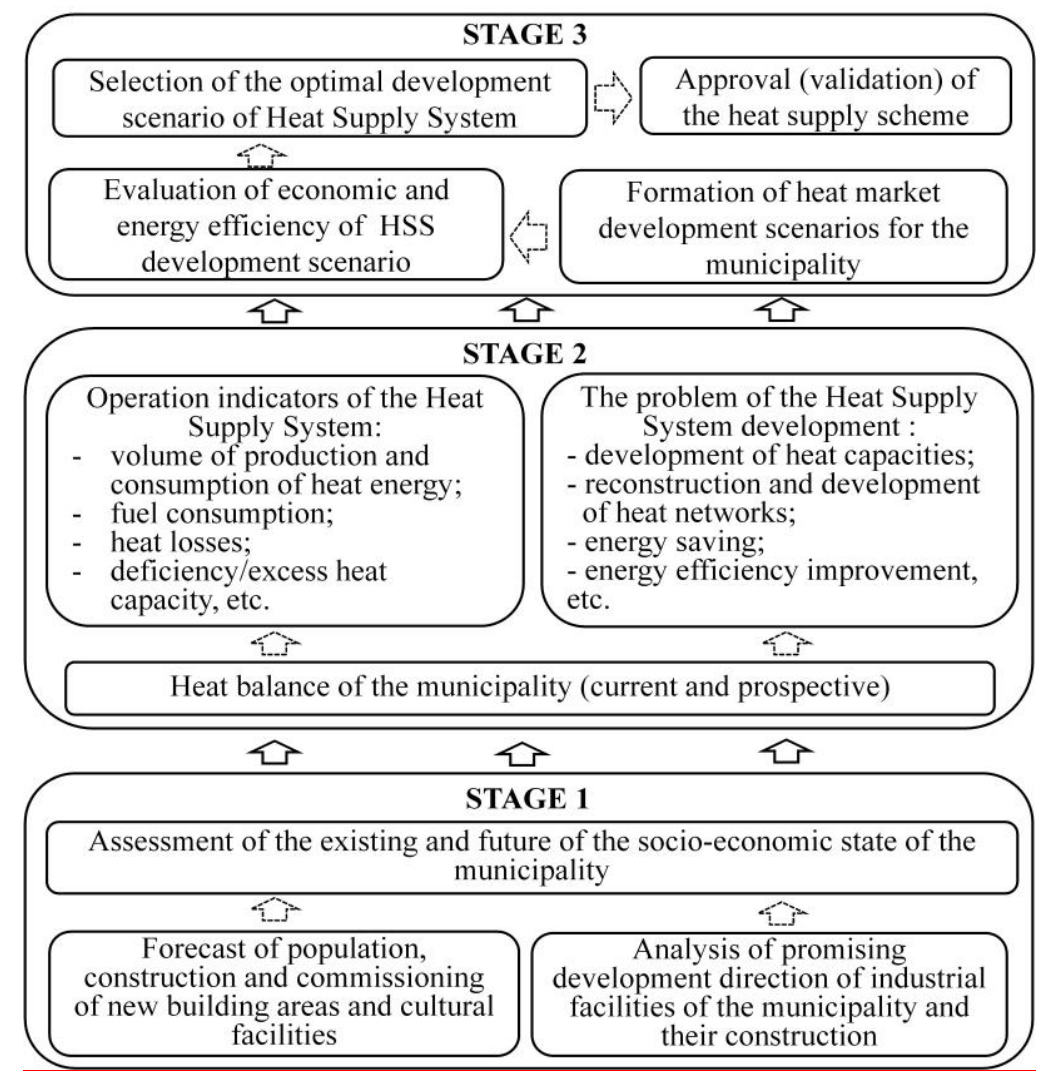

Fig. 1. The methodology of design efficient and reliable heating systems. 
Stage 1. Data on the population's appeal to energy supply companies are processed to identify negative situations in the field of heat supply. A search and analysis of bottlenecks in the heating system is performed. Work with the population on the formation and management of their demand [45] from the standpoint of energy saving should be carried out. Mechanisms and incentives are being developed to achieve the goals. The analysis of current and prospective heat loads (considering the input of residential buildings and social facilities) is carried out in order to develop measures for the reconstruction and development of the heat supply system. Socio-economic research is being conducted. The availability of heat supply for the population is estimated. All this may affect the development and quantification of measures to modernization and reconstruction of the heat supply systems. Industrial heat consumption potential taking into account new industrial facilities in the municipality is estimated. Strategies for the development of the heat supply system of the city with the choice of priority technologies and equipment are being selected. The development plan of municipality territory is being corrected in order to reveal possible locations of heat supply system objects.

Stage 2. A balance of heat energy is being drawn up. Heat consumption and production are calculated. The level of transmission heat losses is estimated. The excess or deficiency of heat capacity is determined for such cases as rising or falling demand of heat energy in the future. On the basis of heat balances, technical and economic assessment of the heat supply system is carried out. Such assessment should include:

- Calculation of costs of the development of existing heat capacity in the conditions of their shortage;

- Determination of optimal directions for the reconstruction and development of heat networks with an assessment of the costs of their implementation;

- Determination of optimal zones of centralized and decentralized heat supply in a given territory;

- Development of an energy saving program to increase the efficiency and competitiveness of the production and use of heat energy in the heat supply system;

- Justification of the economic feasibility of construction of new or renovating existing heat sources;

- Calculation of reliability of heat supply system.

Stage 3. Composition of the proposed options for the development and reconstruction of the heat supply system is formed and the optimal one is chosen. Choice of the optimal variant for the development of heat supply system in market conditions is inappropriate to carry out by the criterion of the minimum total costs of the system. In modern conditions, heat supply industry is represented by many owners, which have their own interests. To owner was interested in the development of their assets, it is necessary to stimulate. According to the theory of microeconomics, such an incentive can be the maximum profit when making decisions on the management of the functioning and development of the heat supply system. Due to the individuality of the economic, energy, territorial conditions in each of the considered municipality, the modelling of heat energy demand is a separate important problem and requires a deep and thorough analysis of the current situation for a specific heat supply system. This will allow correct and adequate planning of activities for the functioning and development of the heat supply system. 


\section{DiscuSSION}

In Russia there is no single developed document like the Heat Supply plan in Europe. Moreover, Russia's energy strategy does not pay due attention to the heat supply problems. There are no approved methods on heat supply planning at any of the levels: urban, regional, national.

Consequently, developers employ available methods, which are in some cases reduced to an analysis of current situation in heat supply without development of projects for modernization of energy infrastructure, without the cost-effectiveness assessment of the use of a district or individual heat supply in the city districts under construction, etc. Although, to develop strategic documents in the field of heat supply it is first of all necessary to determine the conditions under which the construction and operation of DHS will be economically viable, make maps of heat load density, identify the zones of district heating and decentralized heating, and determine the zones of cost-effectiveness of each source in the zone of district heating.

Of a special concern is organizational approaches to the selection of those who will implement the strategic regional and municipal documents. According to [46], the local authorities are obliged to hold an open competition in the development of a heat supply scheme. The participants in the competition can be any organizations that meet the announced requirements to the contractors. This however has the downsides because not always the organization from another region can consider local features of DHS development within tight deadlines. On the other hand, not all the cities have the organizations that have sufficient experience in the development of such projects. Thus, the quality of the developed documents does not always meet the required level. This problem can be solved by introducing long-term (5 years) contracts for development and update of the heat supply scheme in each city, and by making a ledger of unscrupulous contractors. This, however, requires a change in the current legislation.

\section{Conclusions}

Currently the heat supply of the country undergoes reformation. This implies changes in the structure of management, principles of system construction, technologies of operation, tariff regulation, etc. The reforms aim to enhance the efficiency, reliability, and quality of heat supply to consumers. According to the regulatory acts currently in effect in Russia, heat power industry is placed under obligation to develop the documents of prospective design, and this requires advancement of a methodological framework, and organizational and economic decisions to be made. There is also understanding of the fact that the successful management of the DHS development for different time horizons is of great social and economic importance. Positive changes can be achieved by making economically and environmentally informed decisions to plan, design and operate DHS. Application of comprehensive methods for solving stated problems at all temporal stages of DHS development will improve the efficiency of heat production, transmission and consumption.

Heat supply should be planned on the three territorial levels: country, region and district. This is explained by the interaction of the heat power sector with other energy systems and fields of economic activity. Planning the expansion of electric power systems should consider the effectiveness of cogeneration power plant operation and be oriented tow ard an optimal 
coefficient of cogeneration. It is difficult to forecast the development of social and economic sphere without considering the capacities of heat and electricity supply to consumers.

Planning and design of urban DHS represent a complex problem [47]-[50]. The way how it is accomplished depends on both the scales of the required capital investment in engineering equipment of developing cities and appropriate working and domestic conditions in these cities, in particular through the measures aimed at protecting the atmosphere, soil and water bodies from pollution, and providing the required level of comfort and reliability of heat supply.

All things considered, the effective legislation in the field of heat supply should be supplemented with the appropriate methodological framework. Moreover, it is necessary to regularize the rules of interaction between all the heat market participants within the law "On heat supply" since this will enhance of the efficiency of the industry management. There is a need for reforms in the system of setting heat tariffs and charge for connection to the heating systems to liberalize the pricing, foundation of adequate investment funds to $\mathrm{m}$ carry out modernization and development of systems. At the same time, all these should ensure readiness of the consumer to receive heat and opportunity to pay for it.

District heating objectively has technical and economic advantages in countries with a cold climate and it is the basis for the creation of innovative systems with the appropriate state policy. However, it is necessary to regulate the operation of the decentralized heating sector, especially the environmental aspects. The paper lays stress on the need for cooperation of all participants in heat supply: consumers, heat supply enterprises, the state and science, because transformations of DHS should not only be cost-effective, but also stimulate further modernization of the systems. In turn, available quality heat supply to consumers will provide a positive social effect as heat supply is a socially important industry in Russia.

\section{ACKNOWLEDGEMENT}

The study was carried out at Melentiev Energy Systems Institute SB RAS within the framework of research projects III.17.4.1. № AAAA-A17-117030310432-9.

\section{REFERENCES}

[1] Levin L. I., et al. Scientific and Technical Progress in District Heating and Cogeneration (Soviet Technology Reviews Book Series. Section A. Energy Reviews, Vol. 4). UK: Taylor \& Francis, 1990.

[2] Nuorkivi A. District heating and cooling policies worldwide, in: Advanced District Heating and Cooling (DHC) Systems. Woodhead Publishing is an imprint of Elsevier, 2016:17-41.

[3] Russian Federation Federal law of 27.07.2010 No.190-FL (edit. of 29.07.2017). On heat supply. Moscow. (in Russian)

[4] Urban Development Code of the Russian Federation of 29.12.2004 No.190-FL. (in Russian)

[5] Order of the Ministry of the Regional Development of the RF of May 26, 2011 No.244 "On approval of the Methodological recommendations for the development of draft general plans for settlements and urban districts". (in Russian)

[6] Resolution of the State Construction Committee of the Russian Federation of October 29, 2002 No.150 "On Approval of the Instruction on the Procedure for the Development, Approval, Examination and Approval of City Planning Documentation". (in Russian)

[7] Gong M., Werner S. Mapping energy and exergy flows of district heating in Sweden. Energy Procedia 2017:116:119127. doi:10.1016/j.egypro.2017.05.060

[8] Werner S. International review of district heating and cooling. Energy 2017:137:617-631. doi:10.1016/j.energy.2017.04.045

[9] Christensen B., Jensen-Butler C. Energy and urban structure: Heat planning in Denmark. Progress in Planning 1982:8(2):57-132. doi:10.1016/0305-9006(82)90008-3 
[10] Kristensen P. R., Sletbjerg M. Energydata - planning and analysis in a GIS. Proceedings of the ESRI User Conference, Munich, 1998.

[11] Möller B. A heat atlas for demand and supply management in Denmark. Management of Environmental Quality: An International Journal 2008:19(4):467-479. doi:10.1108/14777830810878650

[12] Persson U., Werner S. Heat distribution and the future competitiveness of district heating. Applied Energy 2011:88(3):568-576. doi:10.1016/j.apenergy.2010.09.020

[13] Werner S. District heating and cooling in Sweden. Energy 2017:126:419-429. doi:10.1016/j.energy.2017.03.052

[14] Pol O., Schmidt R.-R. Development of district heating and cooling in the urban planning context, in: Advanced District Heating and Cooling (DHC) Systems. Woodhead Publishing is an imprint of Elsevier, 2016:319-337.

[15] Connolly D., et al. Heat Roadmap Europe: Second Pre-Study. Aalborg University, Halmstad University, Ecofys Germany GmbH, PlanEnergi, and Euroheat \& Power, 2013.

[16] Connolly D., et al. Heat Roadmap Europe: Combining district heating with heat savings to decarbonise the EU energy system. Energy Policy 2014: 65:475-489. doi:10.1016/j.enpol.2013.10.035

[17] Heat Roadmap Europe 4. Heating and Cooling, Facts and Figures. [Online]. [Accessed 15.01.2019]. Available: http://www.heatroadmap.eu/

[18] Persson U., Möller B., Werner S. Heat Roadmap Europe: Identifying strategic heat synergy regions. Energy Policy 2014:74:663-681. doi:10.1016/j.enpol.2014.07.015

[19] Dalla Rosa A., Li H., Svendsen S. Method for optimal design of pipes for low-energy district heating, with focus on heat losses. Energy 2011:36(5):2407-2418. doi:10.1016/j.energy.2011.01.024

[20] Schmidt D., et al. Low temperature district heating for future energy systems. Energy Procedia 2017:116:26-38. doi:10.1016/j.egypro.2017.05.052

[21] Harrestrup M., Svendsen S. Heat planning for fossil-fuel-free district heating areas with extensive end-use heat savings: A case study of the Copenhagen district heating area in Denmark. Energy Policy 2014:68:294-305. doi:10.1016/j.enpol.2014.01.031

[22] Nielsen S., Möller B. GIS based analysis of future district heating potential in Denmark. Energy 2013:57:458-468. doi:0.1016/j.energy.2013.05.041

[23] Sperling K., Hvelplund F., Mathiesen B. V. Centralisation and decentralisation in strategic municipal energy planning in Denmark. Energy Policy 2011:39(3):1338-1351. doi:10.1016/j.enpol.2010.12.006

[24] District Heating and Cooling, Combined Heat and Power and Renewable Energy Sources. The Baltic Sea Region Energy Cooperation. [Online]. [Accessed 15.01.2019]. Available: http://basrec.net/wpcontent/uploads/2014/06/Appendix\%20-\%20country\%20survey.pdf

[25] Patronen J., Kaura E., Torvestad C. Nordic heating and cooling. Nordic approach to EU's Heating and Cooling Strategy. Copenhagen: Nordisk Ministerråd, 2017. doi:10.6027/09086692

[26] District Heating - Danish and Chinese Experience. Danish Energy Agency, Danish Board of District Heating. [Online] [Accessed 15.01.2019]. Available: https://ens.dk/sites/ens.dk/files/energistyrelsen/Nyheder/district_heating_danishchinese_experiences.pdf

[27] Zhang L., Gudmundsson O., Li H., Svendsen S. Comparison of District Heating Systems Used in China and Denmark. International Journal of Sustainable and Green Energy 2015:4(3):102-116.

[28] Resolution of the Government of the RF of 13.02.2006 No.83 (ed. of 23.08.2014). On the approval of rules for the determining and providing technical conditions for the connection of a capital construction object to the engineering and technical services, and rules of connecting a capital construction object to the networks of engineering and technical services. Moscow. (in Russian)

[29] Resolution of the Government of the RF of 22.02.2012 No.154 (ed. of 07.10.2014). On the requirements to the heat supply schemes, order of their development and approval. Moscow. (in Russian)

[30] Federal law of 30.12.2004 No.210-FL (ed. of 29.12.2014). On the foundations of tariff regulation for utilities. Moscow. (in Russian)

[31] Federal law of 23.11.2009 No.261-FL (edit. of 29.12.2014). On energy conservation and energy efficiency enhancement, and amendments to individual legal acts of the Russian Federation. Moscow. (in Russian)

[32] Resolution of the Government of the RF of 16.04.2012 No.307. On the order of connection to the heating systems and on the amendments to some acts of the Government of the Russian Federation. Moscow. (in Russian)

[33] Order of Ministry of Energy of Russia No.565, Ministry of Regional Development of Russia № 667 of 29.12.2012. On the approval of methodological recommendations on the design of heat supply schemes. Moscow. (in Russian)

[34] Resolution of the Government of the RF of 22.10.2012 No.1075 (ed. of 24.01.2017). On pricing in the field of heat supply. Moscow. (in Russian)

[35] Yufa A., Nosulko D. Complex optimization of heat supply. Kiev: Technika, 1988. (in Russian)

[36] Bashmakov I., Papushkin V. Municipal Energy Planning. Energy Saving 2004:3:5-11. (in Russian)

[37] Resolution of the Government of the Russian Federation of 08.08.2012 No.808 "On the Organization of Heat Supply in the Russian Federation and on Amending Certain Acts of the Government of the Russian Federation". Collection of Legislation of the Russian Federation, 2012, No. 34, Art. 4734. (in Russian) 
[38] Informational and analytical report: Heat power and district heating in Russia in 2014, 2016. Ministry of Energy of the $\begin{array}{lllll}\text { Russian Federation. } & \text { [Online]. } & \text { [Accessed }\end{array}$ http://www.rosteplo.ru/Image/news/2015/07/dokladnenergoCT.pdf (in Russian)

[39] The Order of the Ministry of Regional Development of the Russian Federation of May 26, 2011 No.244 "On Approval of the Methodological Recommendations for the Development of Draft General Plans for Settlements and Urban Districts". (in Russian)

[40] System of normative documents in construction, 1998. Guidance document of the system. Instruction on the procedure for designing and establishing red lines in cities and other settlements of the Russian Federation. RDS 30-201-98. (in Russian)

[41] Methodical recommendations for the development of zoning schemes for the territory of the cities of the MDS 30-1.99, 1999 (approved by the State Construction Committee of the Russian Federation, Minutes No.01-NS-15/7 of 10 June 1999). [Online]. [Accessed 15.01.2019]. Available: http://base.garant.ru/3923558/\#ixzz4XPvnTWJQ (in Russian)

[42] Lund H., Duic N., Østergaard P. A., Vad Mathiesen B. Future district heating systems and technologies: On the role of smart energy systems and 4th generation district heating. Energy 2018:165(A):614-619. doi:10.1016/j.energy.2018.09.115

[43] Schuchardt G. K. Integration of Decentralized Thermal Storages Within District Heating (DH) Networks. Environmental and Climate Technologies 2016:18(1):5-16. doi:10.1515/rtuect-2016-0009

[44] Lund H., Østergaarda P. A., Connolly D., Mathiesen B. V. Smart energy and smart energy systems. Energy 2017:137:556-565. doi:10.1016/j.energy.2017.05.123

[45] Khabdullin A., Khabdullina Z., Khabdullina G., Lauka D., Blumberga D. Demand response analysis methodology in district heating system. Energy Procedia 2017:128:539-543. doi:10.1016/j.egypro.2017.09.004

[46] Russian Federation Federal law "On the contract system of the federal and municipal procurement of goods, works and services for ensuring the state and municipal needs” No. 44 of April 5, 2013. (in Russian).

[47] Stennikov V. A., Yakimets E. E. Optimal planning of heat supply systems in urban areas. Energy 2016:110(1):157165. doi:10.1016/j.energy.2016.02.060

[48] Sennova E., et al. Mathematical modelling and optimization of developing heat supply systems. Novosibirsk: Nauka, 1987. (in Russian).

[49] Vigants E., et al. Modelling of Technological Solutions to 4th Generation DH Systems. Environmental and Climate Technologies 2017:20(1):5-23. doi:10.1515/rtuect-2017-0007

[50] Latosov E., Volkova A., Siirde A., Kurnitski J., Thalfeldt M. Methodological Approach to Determining the Effect of Parallel Energy Consumption on District Heating System. Environmental and Climate Technologies 2017:19(1):5-14. $\underline{\text { doi:10.1515/rtuect-2017-0001 }}$ 